\title{
Medical Science Turns Deadly Substances into Life Saving Ones: Snake Venom as a Treatment Option
}

\author{
Somia Gul, Nameera Ahmad, Urooba Iqbal, Bushra Rubab \\ Faculty of Pharmacy, Jinnah University for Women, Karachi, Pakistan \\ Email: drsomi1983@yahoo.com
}

Received 13 February 2015; accepted 28 February 2015; published 5 March 2015

Copyright (C) 2015 by authors and OALib.

This work is licensed under the Creative Commons Attribution International License (CC BY). http://creativecommons.org/licenses/by/4.0/

(c) (i) Open Access

\begin{abstract}
Background: The word "venom" has always been taken as the synonym for poison or a vile liquid with catastrophic effects. Out of several different venomous creatures, snakes have perked special interest of scientists and researchers in this matter across the world. Many scientists and researchers around the world are trying to explore and put forward the positive aspects of snake venom and in the past years they have come to the conclusion that snake venom has some potential effects against serious ailments like cancer, diabetes and hypertension. Objective: The aim of current research is to make people realize that the snake venom, despite being a deadly poison, may prove to be a treatment option in several rather incurable diseases. Methodology: A survey was conducted that was based on $200(n=200)$ people including common public, medical students and health practitioners to know their general opinion and to awake people regarding the beneficial aspects of snake venom. Result: The study shows that about $48.5 \%$ of them think that snake venom can be used for beneficial purposes, while $31 \%$ think of it only as a deadly poison, whereas $\mathbf{2 0 . 5 \%}$ of the people have absolutely no idea about it. The researchers believe that proteins like "eristostatin" and "contortrostatin" found in the venoms of Asian sand viper and South American rattlesnake respectively have the ability to fight against cancers. "Mambalgins" (from the venom of black mamba) are believed to have analgesic and anti-inflammatory effects. Venoms are also being used in skin care products. Conclusion: We conclude that medical practitioners should come forward and explore more on this topic, so that maybe snake venom can prove to be another successful source of medication for several serious diseases.
\end{abstract}

\section{Keywords}

Snake Venom, Cancer, Hypertension, Diabetes, Medicines

Subject Areas: Pharmacology, Public Health 


\section{Introduction}

Since the beginning of time, the word "venom" has always been regarded as the synonym for poison or a vile liquid with catastrophic effects [1]. There are many creatures that have a venomous bite as their defense mechanism; in our minds, the word is usually laced with another horrifying term, "snake-bite", which elicits a fear for life naturally accompanied by excruciating pain. As much as the human minds have developed over centuries and people have started to accept the miracles of science day by day, there will never be a short of people who loathe even the sight of venomous creatures.

However, the world is constantly changing. With thousands of new ideas and theories being thrown at the doors of science, it is high time for a change of conventional thoughts with definite proofs. Snake venoms are complex mixtures of numerous moieties like proteins, peptides, enzymes, toxins and other non-proteins [2] [3] and possess toxic, yet therapeutic qualities [3]. Over the past years scientists and researchers have been trying to bring out the best use of the venom produced by various species of snakes [4]. During these attempts, they have analyzed hundreds of different samples and have come across the properties of snake venom that can result in its better use - the welfare of mankind [5].

According to recent studies, snake venom can be helpful to cure serious and life threatening diseases like cancers, diabetes and hypertension. New research indicates that the toxic venom from poisonous reptiles can change back to harmless proteins within the creature system and that this reversal of function can hold a key to creating drugs that can treat everything from high blood pressure to cancer [6]. A team of UK-based scientists regarded venom of being "unexpectedly dynamic", and said that this finding required a major reassessment of our previous understanding of how animal venoms evolved [7]. According to Dr. Wolfgang Wuster of Bangor University, many snake venom toxins target the same physiological pathways that doctors would like to target to treat a variety of medical conditions. Dr. Nicholas Casewell comes to a conclusion that the evolution of venoms is a really complex process. He notes that the venom gland of snakes appears to be a melting pot for evolving new functions for molecules, some of which are retained in venom for killing prey, while others go on to serve new functions in other tissues in the body [7] [8]. According to Australian researcher Gavin Huttley, understanding how venom works is just another tool in the arsenal to provide opportunities to target human diseases that we really want to fix [7]-[9].

According to a study published in Toxicon, the disintegrin "eristostatin" from the venom of the Asian Sand Viper could be helpful in the fight against melanoma and other cancers [10]. It prevents victims' blood clotting and plugs up damaged blood vessel after the bite; as a result, the victim gets weakened by increased blood loss. Dr Hailey hopes to make use of this tendency of eristostatin to encourage the immune system to attack melanoma cells. In his opinion, eristostatin should be as attracted to cancer cells as it does to platelets. [11]

Another disintegrin "contortrostatin", present in the venom of southern copperhead, also seems to be attracted to cancer cells [12] [13]. Crotoxin, present in the venom of South American rattlesnake, is well known for its immunomodulatory, anti-inflammatory, anti-microbial, anti-tumor and analgesic actions [11]. Celtic Biotech (Dublin) is running a series of tests using this molecule on cancer patients at the Georges Pompidou European Hospital in Paris. The researchers believe that it should be effective on all solid tumors. If those trials go successfully, they are planning to use it for lung cancer [11].

Disintegrins present in the snake venom are also being regarded as potent inhibitors of various integrins [13]. There are three categories of disintegrins according to their integrin selectivity, namely RGD-disintegrins, MLD-disintegrins, and KTS-disintegrins [14]. Out of these, mostly the RGD-disintegrins have been investigated over the years that result in the synthesis of eptifibatide and tirofiban which are currently being evaluated for the treatment of acute coronary ischaemic syndrome [15].

Captopril is a drug based on the peptides from the venom of Brazilian pit viper (Bothrops jararaca), used for lowering the blood pressure [4] [16]-[19].

Hannalgesin is yet another venom based drug made from the venom of the King Cobra. Kini Manjunatha of the National University of Singapore is developing this substance as a pain-relieving agent. He claims it to be between 20 and 200 times more effective than morphine. However unlike morphine, hannalgesin can be taken by orally [11] [20] [21].

According to another study, Mambalgins, proteins present in the venom of black mamba snakes, were discovered in the search for an alternative to opiate drugs such as morphine [20] [22] [23]. Eric Lingueglia (a molecular physiologist at the Institute of Molecular and Cellular Pharmacology in Valbonne, France) and his col- 
leagues deduced that the proteins from the venom of black mamba (Dendroaspis polylepis) possessed anti-inflammatory activity. Meanwhile, mambalgins do not act on opioid receptors but they bind to and inhibit the molecules in the family of acid-sensing ion channels (ASICs) [21].

Neurotoxins target the central nervous system cease muscles stopping them from working. These venoms contain such proteins that are used to treat any type of brain injuries, strokes, various pain disorders, and even the diseases like Alzheimer's disease and Parkinson's disease [23].

In addition to being a possible cure for serious ailments, snake venom also happens to be beneficial for the skin problems. According to a study, snake venom cream is the latest skin care product that ensures wrinkle-free skin without any surgery [24]. Well, isn't that a dream coming true!

It is rather an undeniable fact that the snake venom is extremely dangerous and life-threatening, but it should be noted that it does possess some miraculous qualities due to which it may qualify to be a successful treatment option in the future. The current research aims to make people aware of the positive aspect of snake venom and make them give a thought over the possible use of snake venom in different medications.

\section{Methodology}

A Closed ended questioning survey was conducted regarding the topic of "Benefits of Snake Venom". In this survey, not only the people of different localities but also the students of different educational institutions and professionals at different healthcare centers were evaluated. Data was collected within 25 days or around one month of August, 2014. This survey was based on online data collection and a specially designed questionnaire, which comprised of 16 questions. It was distributed within the population of 200 individuals in order to know that how many of the total population have knowledge about the beneficial aspects of snake venom. Also, the types of venom, effectiveness of snake venom, its use in the treatment of certain diseases like hypertension, diabetes and cancer covered in this analysis. We also analyzed people's knowledge over the basic constituents of snake venom which used in medicines, the drugs which are based on these constituents and also what people think about the cost of the treatment. We also took a general idea of different people about the future prospects of venom virtues.

\section{Data Analysis}

The data was collected through a printed questionnaire based on 16 questions. This questionnaire was distributed to a total of 200 individuals $(n=200)$ between the ages of 18 - 70 years to get the general views of people of different ages regarding the topic of study. People responded to the questionnaire in written form. Evaluation of the answers and calculations were done manually or by the help of calculators without any involvement of computer software.

The result was expressed in percentages by using bar graphs and pie charts. Bar graphs were used to evaluate that how many people know about snake venom (Figure 1). Pie charts were used to analyze the number of people who were treated by snake venom derivatives (Figure 2) and to evaluate the spectrum of snake venom in different diseases (Figure 3).

\section{Result \& Discussion}

All the questionnaires distributed among 200 individuals were shown keen interest and participation from the people in the study $(100 \%)$. Out of 200 , according to age, $50 \%$ of the population was youngsters, $30 \%$ were adults and $20 \%$ comprised of elderly people. According to occupation, $45 \%(90 / 200)$ were students of different departments, $28 \%$ (56/200) medical students, $14 \%$ (28/200) were medical professionals, while 13\% (26/200) were common people. The data collected through the survey results shows that majority of the people $(48.5 \%)$ do think that the snake venom can serve as a beneficial tool, if used correctly (Figure 1). Then there are some people who think of it as a deadly poison and nothing else, and a few of them, have absolutely no idea about it (Figure 1). Besides this, there are some people who have had been treated by snake venom or medicines based on it, but the ratio is low (Figure 2). The study shows that most of the cases, in which snake venom was used as a therapy, were of cancer (34.5\%). The second most treated disease by snake venom was found to be hypertension (23.63\%). $22 \%$ of the people were treated for different pains, $16 \%$ of the cases were of diabetes while $3.6 \%$ of the people opted the category of other diseases (Figure 3). People gave quite a positive response regarding 


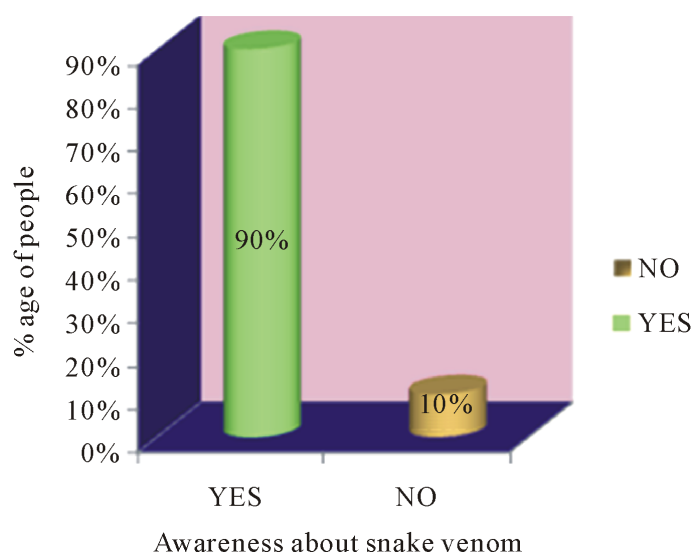

Figure 1. Knowledge about snake venom.

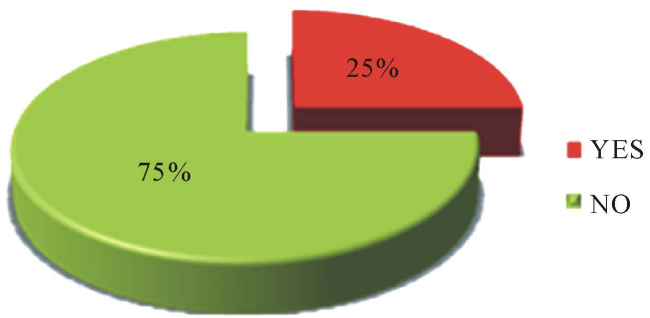

Figure 2. People treated by snake venom.

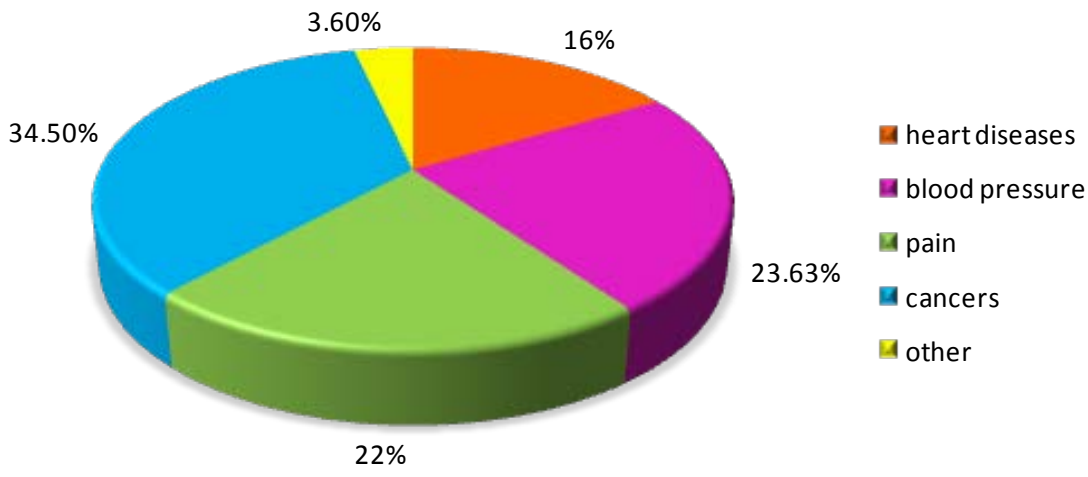

Figure 3. Diseases that have been treated by snake venom.

the future prevalence of this therapy. This data indicates that despite of being experimented and studied time and time again, snake venom is still feared by people and even after knowing about the beneficial aspects of snake venom, people still hesitate to come forward and use it as an alternative therapy.

Numerous researches concerning the matter have shown that venomous snakes have the exclusive ability to convert the toxins present in their venom into harmless components. Scientists and researchers working in this area think that this ability of the venomous snakes may prove to be the basis of therapeutic use of their venom. Besides the hesitance shown by the medical professionals, there are some drugs that are successfully being used world-wide that are based on snake venom constituents, for example: Hannalgesin-used as an analgesic and Captopril - an ACE inhibitor drug used as an anti-hypertensive. Phospholipase type $A_{2}$ is a constituent of snake venom which used as an anti-tumor, Purine \& Pyrimidine-used as hypotension as mentioned in the Table 1. Also, there are some types of snake venom like cytotoxin, neurotoxin, hemotoxin. Each type has a specific function such as, cytotoxin obtained from rattle snake is used to destroy cells, muscle cells/tissues; neurotoxin present in king cobra has an activity of Fast degeneration of synaptic nerve, respiratory arrest, and convulsions as shown in the Table 2. Snake venom is also being used in the composition of anti-aging creams by different 
Table 1. Snake venom constituents according to the snake family and their activity [26] [27].

\begin{tabular}{ccc}
\hline Constituents & Family of Snake Venom & Activity \\
\hline Phospholipase type A2 & $\begin{array}{c}\text { Tunisian, vipers, cerastes, } \\
\text { Macrovipera lebetina }\end{array}$ & Anti-tumor, Anti-cancer \\
Myotoxin & Viperidae & Analgesic \\
Purine \& pyrimidine & Elapidae, viperidae & Hypotension \\
\hline
\end{tabular}

Table 2. Showing types of venom, their actions on body \& snake famous for the activity [25].

\begin{tabular}{ccc}
\hline Types of Snake Venom & Action & $\begin{array}{c}\text { Name of Snake } \\
\text { (Most Famous for the Action) }\end{array}$ \\
\hline Cytotoxin & $\begin{array}{c}\text { Destroys cells, muscle cells/tissues } \\
\text { Neurotoxin }\end{array}$ & $\begin{array}{c}\text { Fast degeneration of synaptic nerve, } \\
\text { respiratory arrest, convulsions } \\
\text { RBC destruction, attacks circulatory } \\
\text { system, blood clotting mechanism } \\
\text { disturbance due to blood poisoning }\end{array}$ \\
\hline
\end{tabular}

brands across the world. The introducers of these anti-aging creams claim that these creams successfully remove wrinkles and other signs of aging without any surgery. Although snake venoms are extremely potent deadly poisons, but if the proper dosing is done by keeping all the parameters and precautions in mind, these venoms may prove to be something other than a threat. These venoms, like any other beneficial drug, can call for a revolution in the history of medicine. Any drug, if the dosing is incorrect, may cause serious problems for humans, even life threatening. So is the case of snake venom.

Despite the various miraculous health benefits of snake venom, it is still not in common practice to be treated by snake venom or its derivatives. This is mainly because of people's fear of the word venom and especially when it is coming from snakes. Usually, if tell someone to use a medicine which is made up of snake venom or to use a non venom based medicine, he would opt the later one. The biggest challenge in the way of introducing snake venom based medicines is to completely and successfully eradicate this fear from people's minds and to enlighten them with the fascinatingly advantageous features of snake venom. This would definitely be a hard nut to crack! But if we successfully help people to overcome their fright and uncertainty regarding snake venom based medicines, this would provide medicine yet another alternative treatment option and would bring a revolution in the field of pharmacy.

\section{Conclusion}

The study highlighted some thought provoking facts concerning a toxin being a medicine. The facts and figures highlighted in this study are that people, whether they are related to the field of medicine or not, do have some know-how about the snake venom and its merits and demerits, but there is still some hesitance from medical practitioners to make full use of it. In this era where we encounter new diseases every passing day, and where old diseases have threaten to hold more severity than ever before, we are in extreme need of new treatment options and more alternatives so as to provide better service to mankind as being a medical servant. We need to explore more and unveil the mysteries that nature has kept hidden for us to get benefits. Snake venom is one of nature's most incredible and miraculous blessings. Although being a poison, it still can save one's life. Snake venom is truly a blessing in disguise!

\section{References}

[1] Moskowitz, C. (2008) Why We Fear Snakes? Live Science, 1. http://www.livescience.com/2348-fear-snakes.html

[2] Vyas, V.K., Brahmbhatt, K., Bhatt, H. and Parmar, U. (2013) Therapeutic Potential of Snake Venom in Cancer Therapy: Current Perspectives. Asian Pacific Journal of Tropical Biomedicine, 3, 156-162.

http://www.ncbi.nlm.nih.gov/pmc/articles/PMC3627178/\#!po=71.8750 
[3] Perkel, J.M. (2008) Snake Venomics Uncoils Venom Composition, Evolution. Journal of Proteome, 7, 3067. http://pubs.acs.org/doi/abs/10.1021/pr800479x http://dx.doi.org/10.1021/pr800479x

[4] Liu, Y., Wang, X.J., Wu, Z., Chen, P., Nie, D.S., Yi, J.M., Yi, J.Z. and Liu, Z.G. (2012) Electrophysiological and Proteomic Studies of Protobothrops mangshensis Venom Revealed Its High Bioactivities and Toxicities. Journal of Integrated Omics, 2, 132-139. http://www.jiomics.com/index.php/jio/article/view/114/106

[5] Paulchamy, C. (2009) Pharmacological Perspectives of Snake Venoms from Viperidae Family. The Internet Journal of Pharmacology, 8, 1. http://ispub.com/IJPHARM/8/2/6664

[6] Fox News (2012) Snake Venom Could Be Used to Treat Cancer, Diabetes. http://www.foxnews.com/health/2012/09/20/snake-venom-could-be-used-to-develop-drugs-for-cancer-diabetes

[7] Cavaliere, V. (2012) Snake Venom Could Hold Cure for Cancer, Diabetes: Study. New York Daily News, 1. http:/www.nydailynews.com/life-style/health/snake-venom-hold-cures-cancer-diabetes-study-article-1.1162830

[8] Jones, T. (2012) Insight into Snake Venom Evolution Could Aid Drug Discovery. Planet Earth Online, NERC-Science of the Environment, 1. http://planetearth.nerc.ac.uk/news/story.aspx?id=1291\&cookieConsent=A

[9] AAP (2012) Snake Venom Could Treat Cancer. The West Australian, 21 September. https://au.news.yahoo.com/thewest/lifestyle/a/14914579/snake-venom-could-treat-cancer

[10] Hailey, S., Adams, E., Peng, R., Wong, A. and McLane, M.A. (2013) Effect of the Disintegrin Eristostatin on Melanoma-Natural Killer Cell Interactions. Toxicon, 6, 83-93. http://www.sciencedirect.com/science/article/pii/S0041010112007751

[11] The Economist (2013) Snake Venom Is Being Used to Cure, Rather than Kill. The Economist, 5 January. http://www.economist.com/news/science-and-technology/21569015-snake-venom-being-used-cure-rather-kill-toxic-m edicine

[12] Pyrko, P., Wang, W., Markland, F.S., Swenson, S.D., Schmitmeier, S., Schönthal, A.H. and Chen, T.C. (2005) The Role of Contortrostatin, a Snake Venom Disintegrin, in the Inhibition of Tumor Progression and Prolongation of Survival in a Rodent Glioma Model. Journal of Neurosurgery, 103, 526-537. http://www.ncbi.nlm.nih.gov/pubmed/16235686

[13] Swenson, S., Costa, F., Ernst, W., Fujii, G. and Markland, F.S. (2005) Contortrostatin, a Snake Venom Disintegrin with Anti-Angiogenic and Anti-Tumor Activity. Pathophysiology of Haemostasis and Thrombosis, 34, 169-176. http://www.ncbi.nlm.nih.gov/pubmed/16707922

[14] Selistre-de-Araujo, H.S., Pontes, C.L.S., Montenegro, C.F. and Martin, A.C.B.M. (2010) Snake Venom Disintegrins and Cell Migration. Toxins (Basel), 2, 2606-2621. http://www.ncbi.nlm.nih.gov/pmc/articles/PMC3153172/\# ffn sectitle

[15] Marcinkiewicz, C. (2005) Functional Characteristic of Snake Venom Disintegrins: Potential Therapeutic Implication. Current Pharmaceutical Design, 11, 815-827.

[16] Zicha, J., Dobesová, Z. and Kunes, J. (2006) Antihypertensive Mechanisms of Chronic Captopril or N-Acetylcysteine Treatment in L-NAME Hypertensive Rats. Hypertension Research, 29, 1021-1027. http://www.nature.com/hr/journal/v29/n12/pdf/hr2006140a.pdf

[17] James Mitchell Crow (2012) Venomous Drugs: Captopril. New Scientist, 214, 35. http://www.sciencedirect.com/science/article/pii/S0262407912611713

[18] Bryan, J. (2009) From Snake Venom to ACE Inhibitor-The Discovery and Rise of Captopril. The Pharmaceutical Journal, 282, 455.

http://www.pharmaceutical-journal.com/news-and-analysis/news/from-snake-venom-to-ace-inhibitor-the-discovery-an d-rise-of-captopril/10884359.article

[19] Miguel-Carrasco, J.L., Zambrano, S., Blanca, A.J., Mate, A. and Vázquez, C.M. (2010) Captopril Reduces Cardiac Inflammatory Markers in Spontaneously Hypertensive Rats by Inactivation of NF- $k$ B. Journal of Inflammation, 7, 21. http://www.journal-inflammation.com/content

[20] Cossins, D. (2013) From Toxins to Therapeutics. The Scientist, 1. http://www.the-scientist.com/?articles.view/articleNo/34745/title/From-Toxins-to-Therapeutics

[21] Shen, H. (2012) Deadly Snake Venom Delivers Pain Relief. Nature, 1. http://www.nature.com/news/deadly-snake-venom-delivers-pain-relief-1.11526

[22] Woolf, C.J. (2013) Pain: Morphine, Metabolites, Mambas and Mutations. The Lancet Neurology, 12, 18-20. http://www.sciencedirect.com/science/article/pii/S1474442212702879

[23] Keber, P. (2013) Using Snake Venom for Medicine. The Weather Network, 1. http://www.theweathernetwork.com/news/articles/using-snake-venom-for-medicine/9860/ 
[24] Rally, D.T. (2010) Viper Room: Is Snake Venom the Cure for Wrinkles? Elle Canada, 1. http://www.ellecanada.com/beauty/viper-room-is-snake-venom-the-cure-for-wrinkles/a/36441/2\#.VAd8OMWSw2A

[25] Bonnier Corporation (2008) Evolution's Most Effective Killer: Snake Venom. Popular Science, 272, 116. http://www.popsci.com/scitech/article/2008-03/evolution\%E2\%80\%99s-most-effective-killer-snake-venom

[26] McCleary, R.J. and Kini, R.M. (2013) Non-Enzymatic Proteins from Snake Venoms: A Gold Mine of Pharmacological Tools and Drug Leads. Toxicon, 62, 56-74.

[27] dos Santos, J.I., Cintra-Francischinelli, M., Borges, R.J., Fernandes, C.A., Pizzo, P., Cintra, A.C., Braz, A.S., Soares, A.M. and Fontes, M.R. (2011) Structural, Functional, and Bioinformatics Studies Reveal a New Snake Venom Homologue Phospholipase $\mathrm{A}_{2}$ Class. Proteins, 79, 61-78. http://www.ncbi.nlm.nih.gov/pubmed/20878713 


\section{Questionnaire}

1) Do you know about snake venom?

Yes, I know

No, I do not know

2) If yes, do you know about different types of venom?

$\square$ Yes

$\square \quad$ No

3) What do you think about venom?

Deadly poison

Poisonous but can be exploited for better use

No idea at all

4) Do you think that snake venom can actually be used in the treatment of certain diseases?

$\square \quad$ If yes, please mention the particular disease

No

5) Have you heard of medicines that include snake venom?

$\square \quad$ No

$\square \quad$ Yes

6) Have you heard of people that have been cured by medicines containing snake venom?

No.

Yes, I have heard of them.

7) If you answered Q6 as yes, then; what were they being treated for?

$\square \quad$ Heart disease.

Pain.

Blood pressure.

Any type of cancer, specify type

Other, specify here

8) If you answered Q6 as yes, then; who treated this person with venom containing medicines?

Allopathic doctor.

Homeopathic doctor.

Other, specify here

9) If you answered Q6 as yes, then, what was the gender of the patient?

Male

Female

10) In which area did you observed these cases mostly?

$\square \quad$ Urban area, specify

$\square \quad$ Rural area, specify

11) Do you know the constituent of venom which used in medicines?

Yes, please specify

No

12) Venomous organisms like snakes are unaffected by their own venom, any idea why is it so?

Yes, please mention the reason

No

13) Do you know of any pharmaceutical companies that use snake venom in their medicines?

$\square \quad$ Yes, please specify

$\square \quad$ No

14) Do you know about the drugs based on snake venom?

$\square \quad$ Yes, please specify the drug

$\square \quad$ No

15) If yes, then do you have any idea of the cost of such medicines?

Expensive

Cheap

No idea 
16) What are the future prospects of venom virtues? Do you have any idea? Yes, please specify

$\square \quad$ No 